\title{
Kambô: A Shamanic Medicine - Personal Testimonies
}

\author{
Jan M Keppel Hesselink ${ }^{1,2 *}$ \\ ${ }^{1}$ Department of Health, University of Witten/Herdecke, Germany \\ ${ }^{2}$ Institute for Neuropathic Pain, Netherlands
}

Submission: August 24, 2017; Published: September 07, 2018

*Corresponding author: Jan M Keppel Hesselink, Department of Health, University of Witten/Herdecke, Germany \& Institute for Neuropathic Pain, Bosch en Duin, Netherlands, Email: jan@neuropathie.nu

\begin{abstract}
Since the beginning of this century more and more people in Europe and USA make use of a shamanic product based on the secretion of an Amazonian frog, the Phyllomedusa bicolor. This secretion contains a great number of bio-active peptides and is administered in a ritual via a fresh burn created on the skin of forearm or leg. The desired effects are related to acute intoxication and consist amongst others of nausea and vomiting, diarrhea and swelling of the face as in Quinke's edema. These effects occur within minutes after the inoculation with the secretion and last mostly for few hours. After this intense period people feel rejuvenated and many participants of the cleansing ritual claim long lasting positive effects for their health. We present the history and context of Kambô use and some case-studies based on personal testimonies. Clearly the increasing use of a shamanic intervention as Kambô is also an expression and a signal of the dissatisfaction of consumers with the results of Western medicine.
\end{abstract}

Keywords: Phyllomedusa bicolor; Shaman; Healing; Target; Side-effects

\section{Introduction}

Phyllomedusa bicolor is an Amazonian frog and the source of Kambô. Kambô is the dried secretion from the frog's skin, a concoction containing many bio-active peptides. These peptides have a broad range of activities related to many potential interesting indications, such as hypertension, chronic pain, anxiety, depression and endocrinology disorders. Frequently new targets are discovered. In in vitro and in vivo models for a number of disorders, many of these peptides have been found to be quite potent, much more potent than the golden standard. However, the bioavailability is not optimal, due to the peptide nature of the compounds.

During the Kambô-ritual the bioactive compounds are introduced in the bloodstream via a fresh burn; the secretion is subsequently rubbed into the wound and thus will quickly enter the blood. This induces a fast action of onset. One can recognize the past experience of a Kambo ritual based on discoloration on the skin due to the healed burns, see Figure 1.

The exact mechanism of action of many peptides is still a matter of debate, as new targets are continuously identified. It is therefore of interest to study the personal experiences of Kambôusers, in order to understand why consumers increasingly turn to this exotic shamanistic intervention.

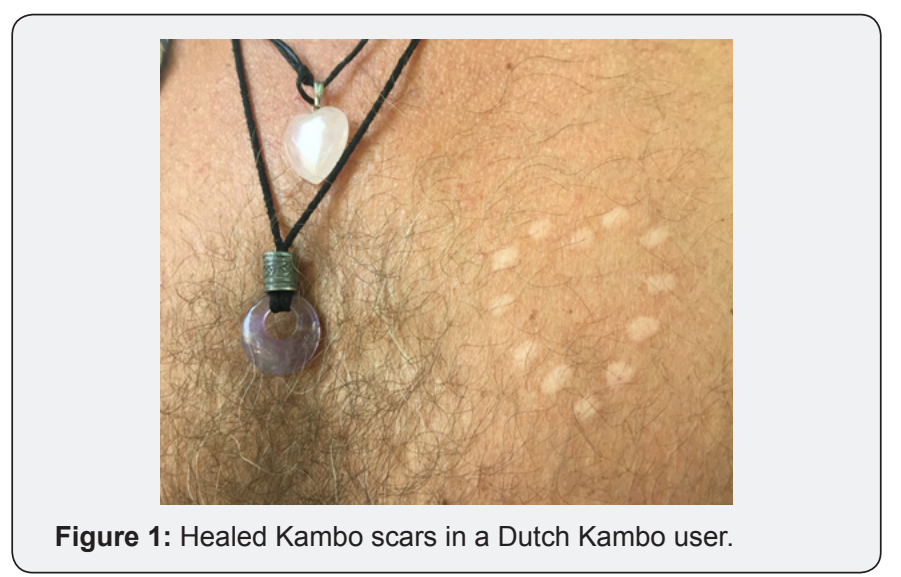

\section{Original use of Kambô}

The early and mythological use of Kambô is suggested to be related to a shaman from the the Kaxinawa tribe in Brazil [1]. This tribe also is known for its use of the strong psychedelic tea Ayahuasca [2]. Kambô was and is used by native Indians from the tribes around the Amazon in various rites, in order to increase their hunting powers [3].

The use of Kambô as a stimulant by indigenous populations of the upper and middle Juruá river was documented in 1925 
by the missionary Constantin Tastevin [4]. He is supposed to be the first author describing the ritual and the purpose of administering Kambô, which he referred to as 'Kachinaua campon'. As his first description contains some important pointers for its current use, we quote Tastevin verbatim:

'When an Indian becomes ill, he becomes thin, pale and swollen; when he is unlucky in hunting, it is because he has in his body a bad principle which must be expelled. At dawn, before dawn, while still fasting, for the sick and unlucky hunter, small scars are produced on the arm or belly with the tip of a burning stick, then they are vaccinated with the "milk" of frog, as they say. Soon violent nausea and diarrhea starts; the bad principle leaves its body by all the exits. As a result, the patient returns from being big and fat and recovers its colors and finds more hunting than he can bring back. No animal escapes from his sharp sight, his ear perceives the smallest noises, and his weapon does not miss its mark [4].

In this first description, the most frequent side effects of Kambô are described: nausea, vomiting, diarrhea, and edema forming as in Quicke's edema. The vomiting and diarrhea are supposed to cleanse the body and the 'bad principle' thus leaves the body and a more vigorous state appears.

In a recent ethnography (2008) the authors describe the diffusion of the use and knowledge of Kampo, due to the members of the Katukina tribe. It is based on their discourse that the use of the secretion as perceived as an 'indigenous remedy', and a very special remedy as it is that the substance is used 'traditionally' both to eliminate 'bad luck', 'panema' (negative energy), and 'weakness and lack in harmony with nature' [5].

In some recent sources in the internet Kambô is claimed to be 'one of the strongest, anti-inflammatory, antibiotic, antimicrobial and anesthetic substances on the planet' [2].

The above context makes it understandable that Kambô is perceived as a therapy for many different disorders. Within shamanic and healing contexts Kambô is often explicitly referred to as 'medicine'.

Katherine Milton, an anthropologist, described Kambô use among the Mayoruna tribe in Brazil in the 1980s and Peter Gorman recorded the use of Kambô within the Matse Tribe in Peru in the same period [6]. Since this century Kambô use has spread to the West, and meanwhile many people are looking for medical solutions via the use of Kambô.

\section{Bio-Active Peptides}

There are a number of different bio-active peptides in the secretion of frogs from the Phyllomedusinae subfamily, and fundamental work on these peptides has been conducted by the group of Erspamer, starting around 50 years ago in the $60 \mathrm{~s}$ of last century [7-10]. Instead of the expected bioactive tryptamines and alkaloids, high amounts of different bio-active peptides were found, belonging to the groups of caeruleins, tachykinins, bradykinins, bombesins, sauvagine (a corticotropinreleasing-hormone-like peptide), tryptophyllins and opioid peptides such as dermorphin. These peptides extracted via methanol from the frog skin have a small molecular mass (700$4600 \mathrm{Da}$ ). Dermorphin for instance was the first peptide found in high concentrations in the skin, of the Phyllomedusinae, about 50-80 ug per $g$ of fresh skin. Dermorphin is a very potent analgesic, in vitro models centrally administered, it is 5001000 fold more potent than morphine [11,12]. However, due to its suboptimal pharmacokinetic properties, its potency after peripheral administration is comparable to morphine. In the lay press so called scientific facts on Kambô are presented without the context outlined above, leading to absurd claims such as: 'Dermorphin and Deltorphin are potent opioid peptides 4000 times stronger than morphine and 40 times stronger than endogenic b-endorphines [3].'

All these Kambô peptides however have indeed impressive endocrine, cardiovascular and nervous system activities [13]. Frequently new targets of these peptides are described, for instance phyllomedusin, has been shown to be quite selective for the Neurokinin 1 receptor [14]. This all creates a whole chapter of various disorders where one or more of these peptides could bring meaningful effects in the treatment of a variety of diseases. The fact that the peptides from the frog's skin are entering the bloodstream after subdermal application (application via a fresh burn), might indicate that plasma-levels after administration could become high. This is probably also the reason why the side-effects start very soon after administration Kambô, within minutes. In how far the effects on disorders can be achieved after a limited series of repeated Kambô-rituals is still unanswered. More detailed case-stories are needed to bring more light in this matter. In this paper, we present some qualitative testimonials, serving to indicate the perceived value of the ritual on a personal basis.

\section{Kambô Testimonials}

Many of these experiences can be found on the net [15], for the purpose of this article we selected only a few and will quote these verbatim:

a) on alcohol addiction,

b) depression,

c) chronic pain,

d) chronic pain with alcohol craving and

e) Hashimoto's thyroiditis and celiac's disease.

i. My first Kambô session knocked me out - literally, I passed out briefly - but it also cleansed my liver and helped me heal a long-term toxic relationship with alcohol. A month after my first Kambô session with Simon, I decided to stop drinking and did so for two years. While I knew it likely wouldn't be a forever thing, my relationship with alcohol and other substances is forever changed, and the break that 
my first experience with Kambô helped me to take gave me a chance to reassess my priorities and learn better selfcontrol.

ii. I feel different. I am different. My life has synchronistically altered to reflect all that has opened and continues to evolve inside me. The emptiness I have carried for so very long is now felt as space permeated by air thick with grace and possibility. The chronic, long-standing grief has been lifted. My heart is both full and light. I simply showed up with the cautious hope that perhaps some of the weight might be left behind. Little did I know that I would be given so much more. The initial euphoria was accompanied by a vision of my life in stunning clarity with a sense of urgency and direction. The beauty of all things whispering to me that it is not too late. It is not too late to live what matters most. I remember now and have been remembered. And that is the gift and the work of it.

iii. Besides having more strength and vitality then I have had since I first became sick 5 years ago, and the pain from my back nerve injury earlier this year completely gone, there is a focus and clarity, a lightness and spaciousness, an otherworldly heightened intuition and perception, a visceral, felt sense of my soul and energy body and its expansiveness, a quietness of the mind I have only ever previously achieved through hours of meditation, and so much more. You can feel the medicine scanning your body and building up intense pressures in certain areas that need healing. Kambô has an intelligence and plan, and each day, each experience, is completely unique. On the third and final day of the 3-day course, I was filled with childlike joy; hysterically laughing, clapping my hands and feet. Somewhere along the way, I learned to stay in line, be quiet, and fit in, so I couldn't help apologizing for my laughter, then laughing even harder at my absurdity of apologizing for being joyful.

iv. After days two and three though I did start to notice some positive changes. I have had chronic lower back, hip and neck pain for the past several years and I noticed by day two that my back pain was almost gone. By the third day I noticed my neck started popping every time I turned it and it felt like it was loosening up and I noticed I could turn it farther to the left and the right. Those were things I was hoping for but not knowing if I would get those types of results or not. Having had problems with alcohol dependency for years was one of the main reasons I went for the treatment and after all three days I didn't have any cravings for alcohol, nor did it even sound good to me, so I was quite amazed at that and very happy. Another big thing for me was I just felt good and in a very positive mood and with more energy than I have had in a long time. Those changes have continued to this day, as I just feel good and in a good mood and enjoy being around my family and friends much more than before. v. Six years ago, I was diagnosed with Hashimoto's thyroiditis and celiac's disease, both of which are autoimmune diseases. Because I fundamentally disagreed with Western medicine's treatment of Hashimoto's (which is to put you on thyroid replacement hormone for the rest of your life, without actually treating the autoimmune system), I had been looking for a treatment that could get at the underlying cause. After years of research, I believed that Kambô might hold the answer. After my experience with Kambô in Peru I stopped taking my Western meds, because the shaman told me I needed to be off of my prescriptions medicines for the Kambô to work. After six weeks, blood work revealed that my thyroid markers had improved, but still indicated hypothyroidism.

\section{Adverse Events}

Because things were better, but not "normal," I decided to go again. A three-day cleanse instead of a single session. Six weeks after the three-day inoculation, my blood work was perfect. Even though I hadn't taken any thyroid medication for over 3 months, all of my thyroid numbers were well within the normal range. Just to be sure, I did another round of blood work just six weeks later and much to my delight, the markers were even better.

We will discuss the adverse events (and transpersonal experiences) in detail in a different paper.

a) Den Brave et al. [16] only reported on some scars on the shoulder of a patient [16].

b) Leban et al. [17] dealt with the emergence of a transient syndrome of inappropriate antidiuretic hormone (SIADH) secretion, due to the combination of Kambô burns, and the drinking of six liters of water after the ritual [17].

c) Pogorzelska and Łapiński [18] dealt with a patient with signs of a transient hepatitis, a chronic history of alcohol and Cannabis use, who used Kambô to maintain abstinence of drinking and smoking [18].

d) Aquila et al. [19] described a sudden death of a 42-old overweight man with signs of coronary pathology [19]. It was suggested that in this case perhaps the hypotensive effects of Kambô could have resulted in reduced myocardial perfusion, tachycardia perhaps leading to a cardiac arrhythmia and sudden death.

e) Li et al. [20] described a 24-year-old woman, brought to the emergency department, due to nausea, vomiting, flushing, facial swelling, altered mental status, and agitation 22h after a Kambô ritual [20].

f) Kumachev et al. [21] described prolonged nausea, very frequent episodes of vomiting, (circa 50), and abdominal discomfort, up to 8 hours after a Kambô [21]. 
g) Roy et al. [22] described a labile woman who took multiple doses of the Kambô and developed a paranoid psychosis, responding well on risperidone [22]. The causality of this case seems questionable.

These reported side effects all were transient apart from the one reported by Aquila et al. [19] and should be a warning to be extremely cautious during a Kambô ritual. It is clear such rituals should and can only be guided by quite experienced moderators, who can differentiate early on between effects which are benign and transient versus life threatening adverse events. Based on case-reports it seems that it is wise to define contra-indications, such as severe cardiovascular conditions and hypotensive syndromes such as Shy-Drager, and to recommend not to drink too much water after a ritual, in order not to provoke a SIADH syndrome. Furthermore, as Kambô seems to be used by the tribes to terminate pregnancies, one would like to exclude pregnant women.

\section{Discussion}

Kambô is used increasingly by Western consumers in order to achieve positive health effects, or to cure certain disorders. This use of a shamanic intervention such as Kambô might also be perceived as an expression and a signal of the dissatisfaction of consumers with the results of Western medicine. It seems a tendency, as more and more consumers also start using healing rituals based on other natural sources, such as the psychedelic tea Ayahuasca.

An increasing number of users report positive effects on a great variety of disorders, from auto-immune disorders up to chronic pain. Kambô contains many bio-active peptides in high concentrations. It is administered into the blood stream via rubbing it in a fresh burn. The effects are immediate and last mostly only for some hours. Many consumers report positive health effects, and effects related to healing. Adverse events have been reported in literature, mostly of transient nature. However, severe reactions can occur, and it is discouraged to use Kambô without the presence of a very experienced therapist. Kambô seems a rich source for new therapies.

\section{References}

1. https://www.Kambôfroghealing.com/history-science/.

2. Lagrou EM (1991) Uma etnografia da cultura Kaxinawa entre a cobra e o inca. Dissertação (mestrado)-Universidade Federal de Santa Catarina. Centro de Ciencias Humanas.

3. http://www.Kambôalchemy.com/medical-research-on-Kambô/.

4. De Lima EC, Labate BC (2008) A expansão urbana do kampo (Phyllomedusa bicolor): notas etnográficas1. Drogas e cultura: novas perspectivas, pp. 315-344.
5. Tastevin C. Le fleuve Muru, La Geographie (2008) Quoted in De Lima, EC en Labate, BC, tomo 1925, XLIII \& XLIV: 14-35 -403-422.

6. Gorman P (1990) People of the Jaguar: shamanic Hunting Practices of the Matses. Shaman's Drum 21: 40-49.

7. Anastasi A, Bertaccini G, Cei JM, De Caro G, Erspamer V, et al. (1969) Structure and pharmacological actions of phyllocaerulein, a caeruleinlike nonapeptide: its occurrence in extracts of the skin of Phyllomedusa sauvagei and related Phyllomedusa species. Br J Pharmacol 37(1): 198-206.

8. Anastasi A, Erspamer GF (1970) Occurrence of phyllomedusin, a physalaemin-like decapeptide, in the skin of phyllomedusa bicolor. Experientia 26(8): 866-867.

9. Erspamer V, Melchiorri P, Falconieri Erspamer G, Montecucchi PC, de Castiglione R, et al. (1985) Phyllomedusa skin: a huge factory and store-house of a variety of active peptides. Peptides 6 (Suppl 3): 7-12.

10. Erspamer V, Erspamer FG, Severini C, Potenza RL, Barra D, et al. (1993) Pharmacological studies of sapo from the frog Phyllomedusa bicolor skin: a drug used by the Peruvian Matses Indians in shamanic hunting practices. Toxicon 31(9): 1099-1111.

11. Fiori A, Cardelli P, Negri L, Savi MR, Strom R, et al. (1997) Deltorphin transport across the blood-brain barrier. Proc Natl Acad Sci USA 94(17): 9469-9474.

12. Negri L, Melchiorri P, Lattanzi R (2000) Pharmacology of amphibian opiate peptides. Peptides 21(11): 1639-1647.

13. Falaschi P, D’Urso R, Negri L, Rocco A, Montecucchi PC, et al. (1982) Potent in vivo and in vitro prolactin inhibiting activity of sauvagine, a frog skin peptide. Endocrinology 111(2): 693-695.

14. Ganjiwale AD, Cowsik SM (2009) Three-dimensional structure of Phyllomedusin, a NK1 receptor agonist bound to dodecyl phosphocholine micelles. J Struct Biol 167(2): 176-184.

15. http://Kambôcleanse.com/testimonials/.

16. den Brave PS, Bruins E, Bronkhorst MW (2014) Phyllomedusa bicolor skin secretion and the Kambô ritual. J Venom Anim Toxins Incl Trop Dis 20: 40 .

17. Leban V, Kozelj G, Brvar M (2016) The syndrome of inappropriate antidiuretic hormone secretion after giant leaf frog (Phyllomedusa bicolor) venom exposure. Toxicon 120: 107-109.

18. Pogorzelska J, Łapiński TW (2017) Toxic hepatitis caused by the excretions of the Phyllomedusa bicolor frog - a case report. Clin Exp Hepatol 3(1): 33-34.

19. Aquila I, Gratteri S, Sacco MA, Fineschi V, Magi S, et al. (2018) The Biological Effects of Kambo: Is There a Relationship Between its Administration and Sudden Death? J Forensic Sci 63(3): 965-968.

20. Li K, Horng H, Lynch K, Smollin CG (2018) Prolonged toxicity from Kambo cleansing ritual. Clin Toxicol (Phila) 2: 1-2.

21. Kumachev A, Zipursky JS, Weinerman AS, Thompson M (2018) Poisoning from the Kambô ritual. CJEM 2: 1-3.

22. Roy R, Baranwal A, Espiridion ED (2018) Can Overuse of Kambô Cause Psychosis? Cureus 10(6): e2770. 
This work is licensed under Creative Commons Attribution 4.0 License DOI: 10.19080/JOJCS.2018.08.555739

\section{Your next submission with Juniper Publishers} will reach you the below assets

- Quality Editorial service

- Swift Peer Review

- Reprints availability

- E-prints Service

- Manuscript Podcast for convenient understanding

- Global attainment for your research

- Manuscript accessibility in different formats

( Pdf, E-pub, Full Text, Audio)

- Unceasing customer service

Track the below URL for one-step submission https://juniperpublishers.com/online-submission.php 